\title{
The Effect of Buzz Group Technique and Clustering Technique in Teaching Writing at the First Class of SMA HKBP I Tarutung
}

\author{
Tagor Pangaribuan $^{1} \&$ Sondang Manik ${ }^{1}$ \\ ${ }^{1}$ Nommensen University, Medan, Indonesia \\ Corresponding: Sondang Manik, Nommensen University, Medan, Indonesia. E-mail: \\ sondang_man1k@yahoo.com
}

Received: September 20, 2017

Accepted: December 18, 2017 Online Published: December 21, 2017

doi: $10.5539 /$ elt.v11n1p164

URL: http://doi.org/10.5539/elt.v11n1p164

\begin{abstract}
This research held at SMA HKBP 1 Tarutung North Sumatra on the research result of test $\mathrm{X}^{2}$ and $\mathrm{XI}^{2}$ students, after they got treatment in teaching writing in recount text by using buzz group and clustering technique. The average score $(\mathrm{X})$ was 67.7 and the total score buzz group the average score $(\mathrm{X})$ was 77.2 and in clustering technique, the average score $(\mathrm{X})$ was 74.5 it mean that there is an improvement of students score after they got treatment. From the score of the test, a calculation was made to find out whether the buzz group and clustering technique significantly affects students writing ability. In Buzz group allows everyone's ideas to be expressed. Students learn to work in real-life situations where others' opinions are considered., in BG sets the groundwork to get discussion, expressing opinions, it is good for dealing with controversial subject Buzz group is significantly effect writing skill of the students.
\end{abstract}

Keywords: Buzz group, clustering technique

\section{Introduction}

English is a global language and is used in such activities, education, technology, social status, and mode rnization. English is one of these language which mostly has roles in educational side. Most of schools in Indonesia take English as the main subject besides German, Japan, Spain, etc. The implication is, students will be able to understand many kinds of things using English language.

Teaching English in Indonesia starting from kindergarten up to university level. Considering the importance of the languages, Indonesia's government has drawn up English as a foreign language that should be mastered by the students. There are four language skills in teaching English, they are; reading, listening, and speaking, writing.

Writing is part of the four skills in addition to listening, speaking, reading should be taught to the maximum by the teacher to the student. Writing is a process of putting thoughts, ideas, opinions, experiences event and history such as writng letters and notes. Writing is one of language skills by which students can express their ideas in written form. It means that they have to be able to write correct sentences and arrange them into a good paragraph. In writing activity, the students are expected to be able to enrich their view about the topic that they want to write well to improving their technique in the writing task. Writing as a process to obtain the product is affected by several elements such as vocabulary, grammar, organization, spelling, and punctuation. Moreover, the purpose of teaching writing is to develop students' writing skills so that students can write in English effectively and efficiently. One of the material studied in high school is a genre. They are twelve genres, they are descrpitive, procedures, narratives, explanations, anecdotes, news, spoof, rebuke exposition, discussion, recount and report text.

Heaton (2005-2008) stated that, "the writing are complex and sometimes difficult to teach, requiring matery not only of grammatical and rhetorical devices but also conceptual and judgemental elements. Writing should be practiced and learned gradually in order to make the students master it well. However, many people agree that writing is a difficult task to do because of its complexity. Such assumpation appear to be true because it really requires many efforts, much time, and great attention from the writer towars the topic must be well in the process itself. 
The writer's experience on teaching practice program in Nommensen HKBP University Economy Department found that most of the students were not able to formulate iedas from their mind into written language. It is proven that most of the students can not write simple paragraph in writing procedure text and as result they got low score in writing. It caused students lacked of understand in grammar, and their vocabularies were limited.

The following case was observed; the students spent a lot of time to write a text. The other students seemed to find it difficult for them to produce what ideas to write. In other words, they had difficulties in expressing ideas to write which has become a problem for them. The students got the problems in organizing their ideas in writing. It seemed that it derives from the fact that they did not use the prewriting techniques to express their ideas before the real writing.Itwas concluded from their statement that they did not know how to start.

In addition some of them also conveyed that they absolutely did not spend much time to look up words in dictionary, even though they were lack of vocabulary. The second, they did not know where to put generic structure of the text, such as in descriptive text, such in descriptive texts identifications and descriptions. The third, the students did a lot of mistakes in using grammar (subject verb agreement) and vocabulary items. For example, they wrote "she tall" and her hair curly. From the description above, it can be seen some problems which are faced by the students in writing descriptive texts. Those problems can be stated as the factors which influence the students' writing. For those reasons, the use of buzz grouptechnique will help the students to express their ideas in writing forms.

One of the important factors for the students in writing skill is using buzz group technique. Buzz Group Technique is a technique that makes students work in small group in limited time. The room soon fills with noise as each sub-group 'buzzes' in discussion. Buzz groups can be in pairs, trios, or more depending on the activity. While they are buzzing, participants are able to exchange ideas and draw on their wide collective experience. (Tarigan Eunike, 2012: 2). Buzz Group is the technique organize the students into group work in time already spesified. In discussion, the class is noise because students' buzzing. Buzz group may be duo, more than two or more. While they are speaking, the other group must share their ideas and explained their large story.

After considering the problems above, both techniques (Buzz Group and Clustering technique) can help students to solve their problem in exploring their ideas in writting skill. The teachers should choose a technique where the students can overcome to write and organize their ideas. In this case, the researcher tries to solve the problem by applying buzz group technique and clustering technique before writing descriptive text or in pre- writing descriptive text, which is assumed to be able to improve students' writing skill. This kind of technique will help the students to get ease developing their ideas in descriptive text.

the object of the study are: to find out the effect of Buzz group technique on students' writing skill., to find out the effect of Clustering technique on students' writing skill, to compare the effect of Buzz Group technique with the Clustering technique on students' writing skill. This research is focused on the effect of Buzz Group and Clustering technique in teaching writing descriptive texts at senior high school at SMA HKBP 1 Tarutung The finding of the study are expected to be theoritically, practically. Theorytically are expected: to be one of the enrichment for the teachers and educational institutions.to enrich the researcher's knowledge who are interested in the research especially related to English teaching technique in writing. to give some contributions to improve the teachers' capability in teaching, the educational institution and other researchers who want to apply the teaching technique.

\subsection{Writing}

Writing is a process to get product is influenced by some elements such as vocabularies, grammar, organization, spelling and punctuation. In writing, some ideas are formed in sentences which are arranged in a good way and related to each other so that the information can be received.

\subsection{Genre}

Genre is kind of text which is describes the general of the text. There are some kinds of reading text such as: narrative, recount, procedure, report, descriptive, spoof, anecdote, etc. The effectiveness of writing genre can be formed two three ways, they are: knowing the purpose of the writing, the good arrangement of text element, and the good grammatical structure.

\subsection{Genre of Writing}

Hyland (2009) says that genre is recognized as types of communicative action to participate in any social events. Besides that, Pardiyono (2007) describes that there are some importance of learning Genre in Writing, they are:

1) Genre serves as the frame of reference in which particular task to be oriental. 
2) It is closely tied with the discussion of communicative purpose (intention) and conventionalized format (rhetorical structure) of a text and linguistic realization

3) Thus, it provides a reference for a particular communicative purpose to achieve stages of the rhetorical structure to cover and linguistic features to stick, by which the reader's expectation can be met effectively.

It provides framework that recognize and share the same features among the people in the related field. It immediate the interrelationship between texts, writers and readers.

From the explanations above, they can be concluded that genre is kinds of type of text has grammatical purpose on the writer in particular social context.

Genre can be recognized from three rhetorical structures. They are social function, generic structure, and lexico grammatical features. Genres differ in terms of their social purposes for which members of a culture interact. They also differ with respects to the stages or schematic structure through which the social processes are achieved.

According to Pardiyono (2007), there are twelve types of genre, they are:

a) Description

Description is a type writing which describes something in detail in order to enable the readers to see, hear, feel, and touch it directly or involve themselves in the event.

b) Recount

Recount is text which tells somebody about something especially that he/she has experience of a series of related events.

c) Procedure

Procedure is a text which explained about how is the process should be done in a sequent step.

d) Narative

Narative is a type of writing which tells an event or process chronologically in a certain time.

e) News Item

News Item is for informing newsworthy events of the day and other natural phenomena.

f) Anecdote

Anecdote is for sharing with others an account of unnusual or amusing even.

g) Explanation

Explanation is to describe the process involved in the information or working of an object or phenomena (explaining a process of information)

h) Discussion

Discussion is for offering viewpoints related to some socio-economic problems.

i) Exposition

Exposition is to carry on an arguments or opinions about something things (for exposing arguments or opinions).

j) Report

Report is for providing information about natural or non natural phenomena

k) Review

Review is for evaluating the quality of books and other works of art

1) Spoof

A spoof is known as a narrative text. It narrates a series of events. It introduces a number of characters.

\subsection{Buzz Group Technique}

The Discussion 66 Method was devised by J. Donald Phillips, past president of Hillsdale College, Michigan, U.S.A. in order to attempt to overcome some of the reasons that people are reluctant to express themselves in group situations. It became known as the Phillips 66 Method after its creator (http://www.brainstorming-howto.com)

According to Mandal (2009), there are many types of cooperative learning strategies. They are Jigsaw, 
Think-Pair-Share, Three-Step Interview, Round Robin, Three-minute review, Numbered Heads, Buzz Groups, Talking Chips, Critical Debate, Write Around, and Praise-Question-Polish. Cooperative learning strategies could be used during the process of writing that is planning, translating and reviewing, so that the product produced by the group is good. During the process of drafting a composition lot of discussions takes place. It encourages the students to think in the language. But the teachers should motivate the students to participate in good discussions. Buzz Group Technique includes one of technique in cooperative learning strategy.

A buzz group is a small group discussion technique which is used to help overcome the problem of silence in group situations and to ensure that everyone gets a chance to contribute to the discussion, within a specific period of time. It is also beneficial because it gives all participants the space and freedom to express themselves equally, thus ensuring that as many creative voices as possible contribute to solving the problem in question.

Large groups may be divided into buzz groups in order to maximize participation. Groups work separately either on the same theme or on separate themes. Each group appoints a spokesperson to report the results of the discussion to the larger group. The typical buzz-group technique is to split the class arbitrarily into small groups and assign each group an objective. Usually a total of six or eight students in a group are optimal.

According to Brewer (1997), Advantages, Disadvantages, and Limitation of the Buzz Group Technique are :

Advantages of the Buzz Group :

1) It allows everyone's ideas to be expressed.

2) Participants leran to work in real-life situations where others' opinions are considered.

3) It sets the groundwork to get discussion started

4) Becuase members are expressing opinions, it is good for dealing with controversial subject.

Disadvantegas of the Buzz Group

1) Effectiveness of the group may be lowered by the immature behavior of a few.

2) It may not be effective for younger groups or groups that know each other to well take each other's opinions seriously.

3) It can be time-consuming when dealing with very large groups.

Limitation of the Buzz Group

1) The group must be well prepared by the teacher in order to keep the group on topic.

2) It is not intended to be a full meeting but used as a supplement to other methods.

\subsection{The Procedure of Buzz Group Technique}

According to Hamilton et al. (1984), to increase students' involvement in discussion and to obtain the benefit of everyone's ideas, the class may be divided into small group of six (or some other small number). First you should explain the specific question to be addressed by the groups and make certain that everyone understand what is to be discussed. It everyone does not understand before discussion begin, many problem can develop. The topic must also be simple enough that students do not become discourage in trying to discuss it in so short time.

The teacher should select or ask each group to select a leader and a recorder. Taking the responsibility for designating competent leaders and recorders can be evaluable learning experience for students. Students should be oriented beforehand to the responsibilities of the leader to make sure that the group sticks to the topic and that all group members participate. In addition, they need to understand the importance of the records job of keeping accurate written records of key items discussed.

Students should be oriented beforehand to the responsibilities of the leader and recorder. They must understand that it is the job of the leader to make sure that the groups sticks to the topic and that all group members participate. In addition, they need to understand the importance of the recorder's job of keeping accurate written records of key items discussed and decision reached and of reporting this information to the total group.

The discussion or "buzzing" should proceed for the short period of time previously designated. The leader should encourage less aggressive individuals to join in the discussion, so that a few highly verbal students do not control the discussion and prevent good group interaction. While the discussion proceeds, the teacher should monitor the progress being made in each buzz group by circulating among the groups. At the end of the discussion, the teacher summarizes briefly and make positive link with happens next. 
The procedure of Buzz Group Technique is as follow:

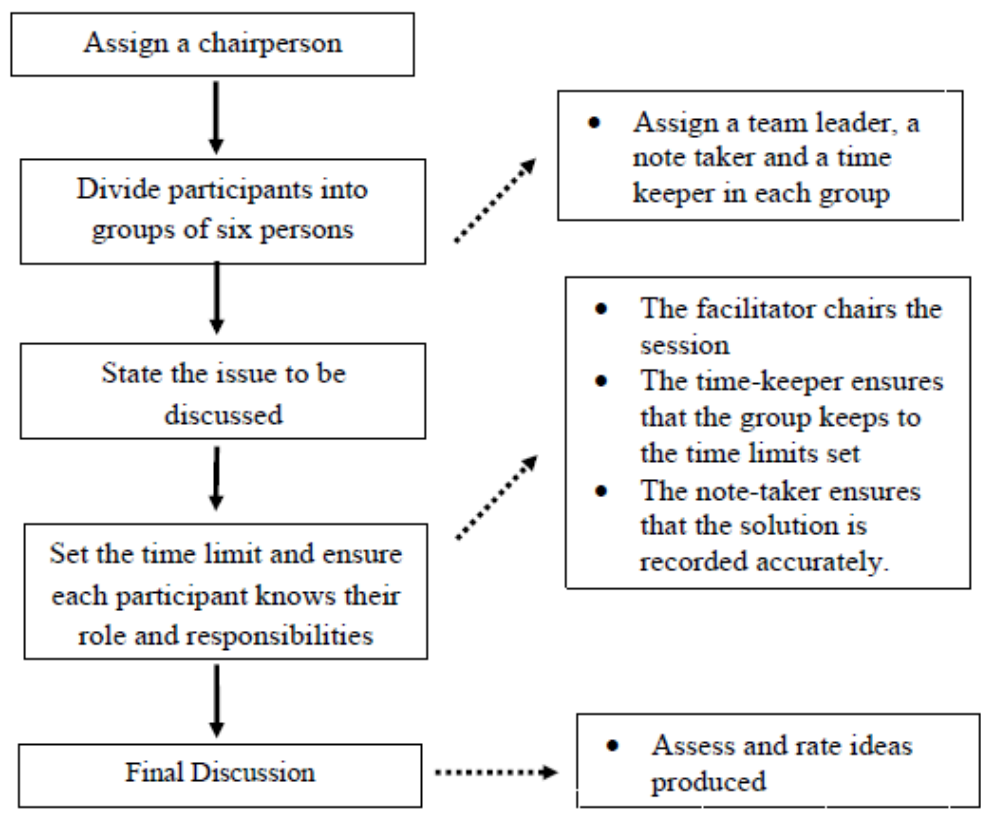

Figure 1. The procedure of Buzz group technique

\subsection{Clustering Technique}

There are some definitions of clustering technique stated by expert, according to Hoshima and Hogue (1991) stated that, define clustering technique as another way of brainstorming technique in pre-writing process besides listing and free-writing that is used generate ideas after topic is chosen and narrowed to a specific focus.

Generally other expects define clustering technique and brainstorming technique as a particular technique that help writer to generate ideas. Contrary, Hoshima and Hogue devide clustering technique as one of brainstorming techniques that can be alternatively used in planning stage besides listing, free-writing or other techniques introduced by other experts.

Alice Hosima and Ann Hogue mentioned that there are some ways or techniques used in pre-writing that is called brainstorming to develop ideas from certain topic after the topic is narrowed. Clustering technique is one of the technique besides listing and free-writing.

As stated above, clustering technique is particular technique can be used in pre-writing stage before a rough draft is develop into two categories; chaotic process and structure processed. Clustering technique is one of the chaotic processes besidesd brainstorming, free-writing, and journaling. He calls clustering technique as mapping or webbing which means that it analayzes the part of the subject in visual way. Clustering technique as chaotic process of pree-writing technique that it depends on the subconcius knowledge that people have. The technique encourages such knowledge to show up so that people can impose order on it. Clustering is classsified into chaotic category because clustering techniques allows people to free their mind in exploring ideas without considering rules of particular structure. The writer just need to write down anything comes in mind, just keep going, and stop when the writer do not have anything in mind to write down.

Clustering is also named as diagramming, is a strategy in producing material for a paper which is helpful for people who like thinks visually. In diagramming, people use lines, boxes, arrows, circles show the connections among the ideas and detail the accour. The rule in diagramming is that there is no right or wrong way of diagramming so that the various ideas and details relate to one another. He implies that clustering technique helps a visual learner in connecting ideas used various and there is no a stric rule that limits the occurred ideas.

Clustering technique is defined as one of the techniques or way to put the ideas into the paper before the writer start to write the dfat. In using clustering, the write makes a circle in the centre of the paper then draws the lines 
while the writer gets the ideas in mind. The writer can free mind from the limitation sentences and paragraphs to produce authentic details and ideas. This is the advantge of clustering technique used in writing in which people can freely write down any ideas come in mind without being afraid of being wrong or worry of whether the ideas is appopriate or not. It is kind of technique in pre-writing that give a bigger space for writer to explore ideas that is essentially abroad.

Based on the definition, the writer concludes that clustering technique is a technique in pre-writing step after the writer focuses or norrows to the specific topic used to ger ideas of writing in visual way which circles and lines are used to connect ideas. Since clustering technique is done in visual way, it is more helpful for the writer who thinks visually in getting ideas before the actually write the first draft of the writing. Clustering technique allows the writer to make his mind fre from limited thought that probably limits the writer's ideas to put them in their writing.

There is no exact rule like which is right and which is wrong in clustering. The writer just needs to write down whatever comes in mind on the paper by connecting them with lines, circles, or boxes. Some experts call it as mapping, webbing or diagramming. As the experts state that there are some pre-writing technique besides clustering that be used to get ideas that are put into a piece of writing, such as; listing, free writing, journaling, etc.

\section{Research Design}

The research designed is a technique which play an important role in the study. This is very important step because it could determine the success or failure of a study. This research is an experimental research where there was a control group and an experimental group. In this research design, the students will be selected randomly by considering that they have the same ability, and the posttest will be given after the researcher gave the different treatment to the two groups. The research design were action that must be performed by a researcher if the researcher wanted to answer the research problem and determined the truth.

In order to know the effect of using buzz group technique and clustering technique in writing descriptive text, the researcher will use the data of the post-test score to see whether the treatment that is given to the experimental class gives a significance contribution to the students ability in writing descriptive text.

Based on the explanation above it could be concluded that the research design was the way how the work was planned and the way how to get the result of the study. This research was Quantitative experimental research. This quantitative research used post test in the end of the research, and experimental design.

\begin{tabular}{cccc}
\hline & Group & Independent Variables & Post-Test \\
\hline $\mathrm{R}$ & $\mathrm{E}_{1}$ & $\mathrm{X}_{1}$ & $\mathrm{O}$ \\
$\mathrm{R}$ & $\mathrm{E}_{2}$ & $\mathrm{X}_{2}$ & $\mathrm{O}$ \\
$\mathrm{R}$ & $\mathrm{C}$ & $\mathrm{Y}$ & $\mathrm{O}$ \\
& Group & Independent Variables & Post-Test \\
$\mathrm{R}$ & $\mathrm{E}_{1}$ & $\mathrm{X}_{1}$ & $\mathrm{O}$ \\
$\mathrm{R}$ & $\mathrm{E}_{2}$ & $\mathrm{X}_{2}$ & $\mathrm{O}$ \\
$\mathrm{R}$ & $\mathrm{C}$ & $\mathrm{Y}$ & $\mathrm{O}$ \\
\hline
\end{tabular}

Explanation:

R: Randomly selected

$\mathrm{E}_{1}$ : Experimental group using buzz group technique

$\mathrm{E}_{2}$ : Experimental Group using clustering technique

C: Control group

$\mathrm{X}_{1}$ : Treatment of experimental group (using buzz group in pre-writing activity)

$\mathrm{X}_{2}$ : Treatment of experimental group (using clustering in pre-writing activity)

Y: Treatment of control Group (without buzz group and clustering in pre-writing activity)

O: Post-Test Result of both experimental and control group.

\subsection{Population and Sample}

In this study will be explained population and sample which can be as sorce data. 


\subsection{Population}

Arikunto (2010), population is whole of subject research, it is defined as all members of any well defined class of people, events, or objects. The population in this study is the first year students of SMA HKBP 1 Tarutung in June 2016. There are three parallel classes namely X1 and X2 and X3. The total of the first year students are 120 students. Each of class consist of 40 students.

\subsection{Sample}

Arikunto (2010), sample is representative of the group or population from which is observed. There are some kinds of sample, they are simple random sampling, stratified random sampling, systematic sampling, area sampling, double sampling and cluster sampling. In selecting the sample the writer uses cluster sampling. Cluster sampling is sample selection which is choosen randomly not individually, but in groups.So, in this study, the sample will be taken by using total sample. Moreover, in order to determine which group belongs to control and experimental groups, the researcher will torn a piece of paper which provides the name of the class. And it will find what class will belong to the experimental group using buzz group, experimental group using clustering and what class will belong to the control group.

\subsection{The Instrument of Collecting the Data}

According to Arikunto (2013), test is a series of questions or exercises as well as other tools is used to measure the skills, knowledge, intelligence, ability or talent processed by individuals groups. The test were taken from text would be written by each group, and then they suitable the generic structure of analytical exposition text. The instrument for collecting data on this study used writing test.

\subsection{Technique of Collecting Data}

The instrument for collecting the data in this study was the score of writing test (writing score) which was derived into the test are post-test to both groups the experimental group and control group. Where the post-test was a test which was conducted after conducting the treatment. The students would be given some paragraphs about analytical exposition text.

\section{Variable}

There are two variables in this research:

1) Independent Variable, variable which is influenced with another variable or treatment that is given to students in experimental classes are buzz group and clustering technique in teaching writing.

2) Dependent Variable, the indication which appear from treatment is result of students' writing cognitive aspects that will be got from writing descriptive text test that will be given at the end research.

\subsection{Technique of Data Collection}

The data of this research will be students' writing descriptive text test scores taken from the post-test given. The test will be given after conducting treatment for about eight meetings. During the research, the three groups will be taught using the same materials but different treatment in pre- writing activity. a experimental group will be taught by using buzz group and another one will be taught by clustering technique in pre- writing activity while the control group will be taught through conventional strategy.

\subsubsection{Validity of the Test}

Validity is one of the most important parts in a good test. According to Gay (2000) validity is concerned with a test which measure what it is supposed to be measured and for whom it is appropriate. It means that the test should be organized based on what students have got and the level of the questions should be suitable with the students' ability. So, to check the validity of the test in this research, the researcher will use the terms of content validity and face validity. Content validity means that the test should measure what the students have learned. Gay (2000) says that content validity is the degree to which a test measures an intended content area. So in this research, the questions will cover all materials that had been taught to the students during teaching and learning process and the test will be also constructed based on the curriculum of SMA HKBP 1 Tarutung, especially the Class X students of writing descriptive text.

Moreover, face validity will be checked by giving the constructed test to the other Writing lecturer at SMA HKBP 1 Tarutung. It is aimed at knowing whether the test will be really a writing descriptive test by considering the test looks right, relevant, fair and useful for improving learning. According Brown (2010), face validity refers to the degree to which a test looks right, and appears to measure the knowledge or abilities it claims to measure, based on the subjective judgment of the examinees who to take it, the administrative personnel who decide on its 
use, and other psychometrically unsophisticated observers.

\subsubsection{Reliability of the Test}

According to Gay (2000) test-retest reliability is the degree to which scores on the same test are consistent over time. This indicates score variation that occurs from one testing session to another. So in this research, the test will be given to a similar group of students for twice.

Post-test scores will be used as data in this research. The data will be analyzed with statistical analysis (t-formula) in identifying whether writing test from the experimental group gives significant result compared with the control group. To see the result, it will be analyzed by using t-formula as follow (Gay, 2000):

$$
t=\frac{(x 1+x 2)-x 3}{\sqrt{\left(\frac{S S_{1}+S S 2+S S 3}{n_{1}+n_{2}+n 3-3}\right)\left(\frac{1}{n_{1}}+\frac{1}{n_{2}}+\frac{1}{n 3}\right)}}
$$

Explanation:

$\mathrm{T}$ : the value of $\mathrm{t}$-calculated

$\mathrm{X} 1$ : mean of the experimental group using buzz group technique

$\mathrm{X}_{2}$ : mean of the experimental group using clustering technique

$\mathrm{X} 3$ : mean of the control group

$\mathrm{SS}_{1}$ : sum of squares of the experimental group using buzz group technique

$\mathrm{SS}_{2:}$ sum of squares of the experimental group using clustering technique

SS3: sum of squares of the control group

$\mathrm{n}_{1:}$ number of experimental group using buzz group technique

$\mathrm{n}_{2:}$ number of experimental group using clustering technique

$\mathrm{n}_{3}$ : number of control group

After calculating the test score by using t-formula, the result finally will be found. If the valuable t-calculated is equal or less than $t$-table at the level of significance 0.05 , it may be concluded that there is no difference between teaching writing descriptive text through buzz group and clustering technique in pre- writing activity and without buzz group and clustering technique in pre- writing activity

If the valuable t-calculated is bigger than t-table at the level of significance 0.05 , it may be concluded that there is a difference between teaching writing descriptive text through buzz group and clustering technique in prewriting activity and without buzz group and clustering technique in pre- writing activity.

\section{The Data Analysis}

The data were the students score in the pre-test and post-test. Both the experimental group and control were given pre-test and post-test in from of writing descriptive text. The result of the classes were presented in the following table.

Table 1. The score of pre-test in experimental class I (Buzz Group)

\begin{tabular}{llllllll}
\hline & & \multicolumn{2}{l}{ Score Of Pre-Test In Experimental Class } & & \\
No & Inisials Name & C & O & V & LU & M & Total \\
\hline 1 & AB & 22 & 10 & 11 & 11 & 3 & 57 \\
2 & AC & 23 & 11 & 12 & 12 & 3 & 63 \\
3 & AD & 22 & 15 & 13 & 13 & 3 & 73 \\
4 & FIZ & 14 & 13 & 14 & 11 & 3 & 55 \\
5 & DS & 20 & 12 & 13 & 13 & 3 & 61 \\
6 & DT & 20 & 12 & 13 & 13 & 3 & 61 \\
7 & DE & 19 & 13 & 15 & 14 & 3 & 64 \\
8 & D & 22 & 15 & 17 & 16 & 3 & 73 \\
9 & ES & 19 & 13 & 16 & 14 & 3 & 64 \\
\hline
\end{tabular}




\begin{tabular}{llllllll}
\hline 10 & HF & 22 & 15 & 17 & 16 & 3 & 73 \\
11 & GT & 22 & 15 & 17 & 16 & 3 & 73 \\
12 & MS & 14 & 13 & 14 & 11 & 3 & 55 \\
13 & HG & 14 & 13 & 14 & 11 & 3 & 55 \\
14 & ON & 17 & 14 & 14 & 15 & 3 & 66 \\
15 & PS & 19 & 13 & 15 & 14 & 3 & 64 \\
16 & TK & 14 & 13 & 14 & 11 & 3 & 55 \\
17 & KIE & 14 & 13 & 14 & 11 & 3 & 55 \\
18 & KI & 17 & 14 & 14 & 15 & 3 & 66 \\
19 & FH & 19 & 13 & 15 & 14 & 3 & 64 \\
20 & TH & 20 & 12 & 13 & 13 & 3 & 61 \\
\hline
\end{tabular}

Based on the students' score of pre-test in experimental class, the students who got score 54 until 69 is 15 students. And students got score 70 until 90 is 5 students.

Note

$\mathrm{C}=$ Content

$\mathrm{O}=$ Organization

$\mathrm{V}=$ Vocabulary

$\mathrm{Lu}=$ Language Use

$\mathrm{M}=$ Mechanism

The result of the students' score in post-test of experimental class can be seen in the following table:

Table 2. The score of post-test in experimental class I (BGT)

\begin{tabular}{llllllll}
\hline & \multicolumn{2}{l}{ Score of Pre-Test In Experimental Class } & & \\
No & Inisials Name & C & O & V & LU & M & Total \\
\hline 1 & AB & 22 & 17 & 15 & 12 & 3 & 69 \\
2 & AC & 23 & 17 & 12 & 13 & 3 & 67 \\
3 & AD & 26 & 19 & 18 & 20 & 3 & 87 \\
4 & FIZ & 22 & 17 & 17 & 17 & 3 & 76 \\
5 & DS & 22 & 12 & 13 & 13 & 3 & 65 \\
6 & DT & 22 & 12 & 13 & 13 & 3 & 65 \\
7 & DE & 22 & 13 & 15 & 14 & 3 & 76 \\
8 & D & 26 & 15 & 17 & 16 & 3 & 87 \\
9 & ES & 22 & 13 & 15 & 14 & 3 & 76 \\
10 & HF & 26 & 13 & 17 & 16 & 3 & 87 \\
11 & GT & 22 & 19 & 17 & 16 & 3 & 87 \\
12 & MS & 22 & 19 & 14 & 11 & 3 & 76 \\
13 & HG & 25 & 13 & 14 & 11 & 3 & 76 \\
14 & ON & 22 & 18 & 18 & 18 & 3 & 83 \\
15 & PS & 22 & 17 & 16 & 17 & 3 & 75 \\
16 & TK & 22 & 17 & 17 & 17 & 3 & 76 \\
17 & KIE & 25 & 17 & 17 & 17 & 3 & 76 \\
18 & KI & 22 & 18 & 18 & 18 & 3 & 83 \\
19 & FH & 22 & 17 & 16 & 17 & 3 & 75 \\
20 & TH & 22 & 17 & 17 & 17 & 3 & 65 \\
\hline
\end{tabular}

The score of post-test in experimental class, the students who got score 65 until 79 was 11 students. And students get 80 until 87 was 7 students. 
Table 3. The score of pre-test and post-test of experimental class I (TPS)

\begin{tabular}{lllll}
\hline & & Score & Post-Test (T2) & T2-T1 (d) \\
No & Inisials Name & Pre-test (T1) & 69 & 12 \\
2 & AB & 57 & 67 & 4 \\
3 & AC & 63 & 87 & 14 \\
4 & FIZ & 73 & 76 & 21 \\
5 & DS & 55 & 65 & 4 \\
6 & SAS & 61 & 65 & 4 \\
7 & DE & 61 & 76 & 11 \\
8 & FR & 64 & 87 & 14 \\
9 & ES & 73 & 76 & 11 \\
10 & TR & 64 & 87 & 14 \\
11 & SW & 73 & 87 & 14 \\
12 & SAQ & 73 & 76 & 11 \\
13 & GT & 55 & 76 & 11 \\
14 & YH & 55 & 83 & 11 \\
15 & TJ & 66 & 75 & 20 \\
16 & JU & 64 & 76 & 20 \\
17 & KIS & 55 & 76 & 17 \\
18 & KOI & 55 & 83 & 11 \\
19 & LO & 66 & 75 & 4 \\
20 & LH & 64 & 65 & 245 \\
Total & & 61 & 1189 & \\
Mean & & 1138 & 77.2 & \\
\hline
\end{tabular}

$$
\begin{gathered}
\frac{M_{1}-M_{2}}{\sqrt{M S_{w}\left(\frac{1}{n}\right)}} \\
\frac{77.2-63.2}{\sqrt{14\left(\frac{1}{18}\right)}} \\
=7.36
\end{gathered}
$$

From the data above showed that there was different score of pre-test and post-test. The means score of pre-test was 63.2 and the means post test score was 77.2 the gap between the means of score pre-test and post-test was 14 . The range of this data indicated there was significant process during teaching and learning using buzz group.

Table 4. The score of pre-test in experimental class II (Clustering)

\begin{tabular}{llllllll}
\hline & \multicolumn{2}{l}{ Score for Experimental Class } & \multicolumn{2}{l}{} \\
No & Inisials Name & $\mathrm{C}$ & $\mathrm{O}$ & $\mathrm{V}$ & $\mathrm{LU}$ & $\mathrm{M}$ & Total \\
\hline 1 & AB & 12 & 13 & 10 & 9 & 2 & 46 \\
2 & AC & 15 & 10 & 11 & 10 & 2 & 48 \\
3 & AD & 22 & 10 & 13 & 13 & 3 & 68 \\
4 & FIZ & 14 & 13 & 14 & 11 & 3 & 55 \\
5 & DS & 20 & 12 & 13 & 13 & 3 & 61 \\
6 & SAS & 20 & 12 & 13 & 13 & 3 & 61 \\
7 & DE & 16 & 13 & 15 & 14 & 3 & 64 \\
8 & FR & 22 & 15 & 17 & 10 & 3 & 68 \\
9 & ES & 19 & 13 & 15 & 14 & 3 & 64 \\
\hline
\end{tabular}




\begin{tabular}{llllllll}
\hline 10 & TR & 22 & 15 & 17 & 16 & 3 & 73 \\
11 & SW & 22 & 15 & 17 & 16 & 3 & 73 \\
12 & SAQ & 14 & 13 & 10 & 11 & 3 & 51 \\
13 & GT & 10 & 13 & 14 & 11 & 3 & 51 \\
14 & YH & 19 & 14 & 14 & 15 & 3 & 66 \\
15 & TJ & 17 & 13 & 11 & 10 & 3 & 60 \\
16 & JU & 14 & 13 & 14 & 11 & 3 & 55 \\
17 & KIS & 19 & 13 & 14 & 11 & 3 & 55 \\
18 & KOI & 15 & 14 & 14 & 10 & 3 & 66 \\
19 & LO & 17 & 13 & 15 & 10 & 3 & 60 \\
20 & LH & 15 & 15 & 10 & 9 & 3 & 68 \\
\hline
\end{tabular}

Based on the students' score of pre-test in experimental class, the student who got score 54 until 69 is 16 . And students got score 70 until 90 is 2 students.

Note

$\mathrm{C}=$ Content

$\mathrm{O}=$ Organization

$\mathrm{V}=$ Vocabulary

$\mathrm{Lu}=$ Language Use

$\mathrm{M}=$ Mechanism

The result of the students' score in post-test of experimental class can be seen in the following table:

Table 5. The score of post-test in experimental class I (TPS)

\begin{tabular}{llllllll}
\hline & \multicolumn{2}{l}{ Score For Experimental Class } & & & \\
No & Inisials Name & C & O & V & LU & M & Total \\
\hline 1 & AB & 20 & 18 & 17 & 10 & 3 & 68 \\
2 & AC & 20 & 17 & 17 & 11 & 3 & 68 \\
3 & AD & 26 & 19 & 18 & 10 & 4 & 77 \\
4 & FIZ & 20 & 17 & 17 & 17 & 3 & 74 \\
5 & DS & 22 & 12 & 15 & 10 & 3 & 65 \\
6 & SAS & 22 & 12 & 13 & 13 & 3 & 65 \\
7 & DE & 22 & 13 & 15 & 10 & 3 & 72 \\
8 & FR & 26 & 15 & 17 & 10 & 3 & 81 \\
9 & ES & 22 & 13 & 15 & 13 & 3 & 75 \\
10 & TR & 26 & 19 & 17 & 12 & 4 & 83 \\
11 & SW & 26 & 19 & 15 & 16 & 4 & 85 \\
12 & SAQ & 22 & 13 & 14 & 11 & 3 & 76 \\
13 & GT & 22 & 13 & 12 & 11 & 3 & 74 \\
14 & YH & 25 & 18 & 18 & 18 & 4 & 83 \\
15 & TJ & 22 & 17 & 16 & 17 & 3 & 75 \\
16 & JU & 22 & 17 & 17 & 17 & 2 & 75 \\
17 & KIS & 22 & 10 & 17 & 17 & 3 & 69 \\
18 & KOI & 25 & 18 & 18 & 10 & 4 & 75 \\
19 & LO & 22 & 16 & 16 & 15 & 3 & 72 \\
20 & LH & 22 & 16 & 17 & 15 & 3 & 65 \\
\hline
\end{tabular}

The score of post-test in experimental class, the students who got score 65 until 79 was 14 students. And students get 80 until 87 was 4 students. 
Table 6. The score of pre-test and post-test of experimental class I (TPS)

\begin{tabular}{lllll}
\hline & & Score & Post-test(T2) & T2-T1 \\
\hline 1 & Inisials Name & Pre-test (T1) & 68 & 22 \\
2 & AC & 46 & 68 & 20 \\
3 & AD & 48 & 77 & 9 \\
4 & FIZ & 68 & 74 & 11 \\
5 & DS & 55 & 65 & 4 \\
6 & SAS & 61 & 65 & 4 \\
7 & DE & 61 & 72 & 8 \\
8 & FR & 64 & 81 & 13 \\
9 & ES & 68 & 75 & 11 \\
10 & TR & 64 & 83 & 20 \\
11 & SW & 73 & 76 & 12 \\
12 & SAQ & 73 & 74 & 25 \\
13 & GT & 51 & 83 & 23 \\
14 & YH & 51 & 75 & 17 \\
15 & TJ & 66 & 75 & 15 \\
16 & JU & 60 & 69 & 20 \\
17 & KIS & 55 & 75 & 14 \\
18 & KOI & 55 & 72 & 9 \\
19 & LO & 66 & 65 & 12 \\
20 & LH & 60 & & 7 \\
Total & & 68 & & \\
Mean & & & & \\
\hline & & & & \\
\hline
\end{tabular}

$$
\begin{gathered}
\frac{M_{1}-M_{2}}{\sqrt{M S_{w}\left(\frac{1}{n}\right)}} \\
\frac{74.5-61.6}{\sqrt{12.9\left(\frac{1}{18}\right)}} \\
=7.17
\end{gathered}
$$

From the data above showed that there was different score of pre-test and post-test. The means score of pre-test was 61.6 and the means post test score was 74.5 the gap between the means of score pre-test and post-test was 12.9. The range of this data indicated there was significant process during teaching and learning using clustering.

Table 7. The score of pre-test in control class

\begin{tabular}{llllllll}
\hline & & \multicolumn{2}{l}{ Score for Experimental Class } & \multicolumn{2}{l}{} \\
No & Inisials Name & C & O & V & LU & M & Total \\
\hline 1 & AF & 18 & 12 & 15 & 14 & 2 & 61 \\
2 & A & 18 & 13 & 15 & 14 & 2 & 64 \\
3 & BG & 20 & 12 & 15 & 14 & 2 & 63 \\
4 & BF & 22 & 16 & 17 & 17 & 3 & 75 \\
5 & CD & 22 & 16 & 17 & 17 & 3 & 75 \\
6 & CG & 20 & 12 & 15 & 14 & 2 & 63 \\
7 & F & 20 & 12 & 15 & 14 & 2 & 63 \\
8 & HN & 20 & 12 & 15 & 14 & 2 & 63 \\
9 & HU & 20 & 12 & 10 & 10 & 2 & 54 \\
10 & JJ & 18 & 14 & 15 & 11 & 2 & 60 \\
\hline
\end{tabular}




\begin{tabular}{llllllll}
\hline 11 & KL & 20 & 12 & 10 & 10 & 2 & 54 \\
12 & K & 20 & 12 & 10 & 10 & 2 & 54 \\
13 & MF & 20 & 12 & 10 & 10 & 2 & 54 \\
14 & R & 18 & 12 & 17 & 15 & 3 & 65 \\
15 & RS & 20 & 12 & 10 & 10 & 2 & 54 \\
16 & TG & 18 & 14 & 15 & 11 & 2 & 60 \\
17 & WG & 18 & 14 & 15 & 11 & 2 & 60 \\
18 & WJ & 22 & 16 & 17 & 17 & 3 & 75 \\
19 & KM & 22 & 16 & 17 & 17 & 3 & 75 \\
20 & KL & 18 & 14 & 15 & 11 & 2 & 60 \\
\hline
\end{tabular}

The score of pre-test in control class, the student who got score 50 until 54 was 5 students, and students get value 65 until 75 was 15 students.

Table 8 . The score of post-test in control class

\begin{tabular}{llllllll}
\hline & & \multicolumn{2}{l}{ Score for Experimental Class } & & & TU \\
No & Inisials Name & C & O & V & LU & M \\
\hline 1 & AF & 20 & 13 & 16 & 16 & 3 & 68 \\
2 & A & 22 & 13 & 16 & 16 & 3 & 70 \\
3 & BG & 21 & 13 & 16 & 16 & 3 & 69 \\
4 & BF & 22 & 14 & 14 & 17 & 3 & 70 \\
5 & CD & 22 & 14 & 14 & 17 & 3 & 70 \\
6 & CG & 26 & 17 & 17 & 20 & 4 & 85 \\
7 & F & 26 & 17 & 17 & 20 & 4 & 85 \\
8 & HN & 20 & 12 & 11 & 11 & 3 & 57 \\
9 & HU & 20 & 12 & 11 & 11 & 3 & 57 \\
10 & JJ & 22 & 14 & 13 & 13 & 3 & 65 \\
11 & KL & 20 & 12 & 11 & 11 & 3 & 57 \\
12 & K & 20 & 12 & 11 & 11 & 3 & 57 \\
13 & MF & 20 & 12 & 11 & 11 & 3 & 57 \\
14 & R & 21 & 13 & 16 & 16 & 3 & 69 \\
15 & RS & 26 & 17 & 17 & 20 & 3 & 85 \\
16 & TG & 22 & 14 & 13 & 13 & 4 & 65 \\
17 & WG & 22 & 14 & 13 & 13 & 3 & 65 \\
18 & WJ & 22 & 14 & 14 & 17 & 3 & 70 \\
19 & KM & 22 & 14 & 14 & 17 & 3 & 70 \\
20 & KL & 22 & 14 & 13 & 13 & 3 & 65 \\
\hline
\end{tabular}

The data in the table above showed that the higest score of the post-test in control group, the highest was 85 and the lowest was 57 .

Table 9. The score of pre-test and post-test in control class

\begin{tabular}{lllll}
\hline No & Inisials Name & Score & Post-test(T2) & T2-T1 \\
\hline 1 & AF & Pre-test (T1) & 68 & 7 \\
2 & A & 64 & 70 & 6 \\
3 & BG & 63 & 69 & 6 \\
4 & BF & 75 & 70 & 5 \\
5 & CD & 75 & 70 & 5 \\
6 & CG & 63 & 85 & 22 \\
7 & F & 63 & 85 & 22 \\
\hline
\end{tabular}




\begin{tabular}{lllll}
\hline 8 & HN & 63 & 57 & 22 \\
9 & HU & 54 & 57 & 3 \\
10 & JJ & 60 & 65 & 5 \\
11 & KL & 54 & 57 & 3 \\
12 & K & 54 & 57 & 3 \\
13 & MF & 57 & 3 \\
14 & R & 54 & 69 & 4 \\
15 & RS & 65 & 85 & 3 \\
16 & TG & 54 & 65 & 5 \\
17 & WG & 60 & 65 & 5 \\
18 & WJ & 60 & 70 & 5 \\
19 & KM & 75 & 70 & 5 \\
20 & KL & 75 & 65 & 5 \\
Total & & 60 & 1218 & 131 \\
Mean & & 1127 & 67,7 & 72,8 \\
\hline
\end{tabular}

$\mathrm{DF}=67.7-62.6=5.1$ 。

The data above showed that there was not the different score od pre-test and post-test. The means score of pre-test was 62.6 and the mean of post-test was 67.7. the gap between the means score of pre-test and post-test 5.1. the range of this data indicated that did not give any effect on students' writing ability.

\section{Testing Hypotesis}

Based on the research result of $\mathrm{X}^{2}$ and $\mathrm{XI}^{2}$ students, after students of SMA HKBP 1 Tarutung got treatment in teaching writing in recount text by using buzz group and clustaring technique. They reached the maximum score 87 and minimum score 65. From the computation of frequency distribution, it was found the total score of conventional teaching $(\mathrm{CT})=1218$, so the average score $(\mathrm{X})$ was 67.7 and the total score buzz group (BG) $=1389$. So the average score $(\mathrm{X})$ was 77.2 and the total clustening $=1341$. So the average score $(\mathrm{X})$ was 74.5 it mean that thre was an improvement of students score after they got treatments.

From the score of the test, a calculation was made to find out whether the buzz group and clustering technique significantly affects students writing ability.

Table 10. One way anova formula

\begin{tabular}{lllll}
\hline Source of variation & Sum of Squares & Df & Mean Squares & f \\
\hline Between Groups & 915.1765 & 2 & 457.59 & 78.19 \\
Within Groups & 2809.176 & 48 & 58.52 & \\
Total & 3724.353 & 50 & & \\
\hline
\end{tabular}

$$
\begin{gathered}
M S_{B e t}=N S \frac{2}{x}=18^{*} 1.9687=35.4366 \\
M S_{\text {With }}=\frac{{S_{1}}^{2}+{S_{2}}^{2}}{2}=\frac{6.08^{2}+5.1^{2}}{2}=\frac{36.9664+26.01}{2}=31.4881 \\
F_{\text {obs }}=\frac{M S_{\text {Bet }}}{M S_{\text {With }}}=\frac{35.4366}{31.4881}=1.126
\end{gathered}
$$

From the criteria of the hypothesis, Ha is accepted F Test $>$ F Tabel. From the calculation above, it is found the F rest is higher than $\mathrm{f}$ table or can be seen as follows:

$\mathrm{F}_{\text {TEST }}$ TPS $>\mathrm{F}_{\text {TEST }} \mathrm{MP}>\mathrm{F}_{\text {TEST }} \mathrm{CT}>\mathrm{F}_{\text {TESs table }}$

$3.36>7.17>5.1>2.92$ 


\section{Conclusion}

Based on the research result of $\mathrm{X}^{2}$ and $\mathrm{XI}^{2}$ students, after they got treatment in teaching writing in recount text by using buzz group and clustering technique. The average score $(\mathrm{X})$ was 67.7 and the total score buzz group $(B G)=1389$. So the average score $(X)$ was 77.2 and the total clustering $=1341$. So the average score $(X)$ was 74.5 it mean that there was an improvement of students score after they got treatments.

From the score of the test, a calculation was made to find out whether the buzz group and clustering technique significantly affects students writing ability. In Buzz group allows everyone's ideas to be expressed. Students learn to work in real-life situations where others' opinions are considered., in BG sets the groundwork to get discussion startare expressing opinions, it is good for dealing with controversial subject.

\section{References}

Alamsyah, M. (2009). KiatJituMeningkatkanPrestasiDengan Mind Mapping.Yogyakarta: Mitra Pelajar.

Best \& Khan. (2002). Research InEducation. America: Wadsworth.

Buzan, T. (2009). Buku Pintar Mind Mapping. Jakarta: PT Gramedia Pustaka Utama.

Buzan, T. (2009). BukuPintar Mind MappingUntukAnak. Jakarta: PT Gramedia Pustaka Utama.

Buzan, T. (2010). How can I improve my study skills with Mind Mapping?

Eppler, M. J. (2006). A Comparison Between Concept Maps, Mind Maps, Conceptual Diagrams, and Visual Metaphors as Complementary Tools for Knowledge Construction and Sharing.

Harmer, J. (2002). How To Teach English. New York : Edinburg Gate.

Istarani. (2011). 58 Model PembelajaranInovatif. Medan: Media Persada.

Pardiyono. (2007). Teaching-genre-basedwriting. Yogyakarta: Penerbit Andi.

Prayogo, A. (2009). Using Mind Mapping in Teaching Descriptive Writing at SMP RiyadlulJannahBogor.Skripsi, English Education Department, Faculty ofTarbiya and Teacher's Training, UIN SyarifHidayatullah Jakarta. Advisor: Hidayati, Dra. M.Pd.

Riswanto \& Putra, P. P. (2012). A Thesis: The Use of Mind Mapping Strategy in the Teaching of Writing at SMAN 3 Bengkulu Indonesia. International Journal of Humanities and Social Science, 2, 60-62.

Sun, C. L., \& Feng, G. P. (2009). Process Approach to Teaching Writing Applied in Different Teaching Models. English Language Teaching, 2(1), 150. https://doi.org/10.5539/elt.v2n1p150

Supriyanto, J. A Thesis: The Effect of Mind Mapping Strategy on the Students' Writing Ability. International Journal JP3, 1, 184-189.

Weigle, S. C. (2002). AssessingWriting.NewWork: Cambridge University Press.

Widura, S. (2008). Mind Map Langkah Demi Langkah. Jakarta: PT Alex Media Komputindo.

\section{Copyrights}

Copyright for this article is retained by the author(s), with first publication rights granted to the journal.

This is an open-access article distributed under the terms and conditions of the Creative Commons Attribution license (http://creativecommons.org/licenses/by/4.0/). 